"This is the peer reviewed version of the following article: [Chem. Eur. J . 2015, 21, $7 \quad 144-7 \quad 150$

], which has been published in

final form at [http://onlinelibrary.wiley.com/doi/10.1002/chem.201500333/abstract]. This article may be used for noncommercial purposes

in accordance with Wiley Terms and Conditions for Self-Archiving ."

\title{
Highly Efficient Chirality Transfer from Diamines Encapsulated within a Self-Assembled Calixarene-Salen Host
}

Luis Martínez-Rodríguez, ${ }^{[a]}$ Nuno A. G. Bandeira, ${ }^{[a]}$ Carles Bo ${ }^{[a, b]}$ and Arjan W. Kleij ${ }^{[a, c]}$

\begin{abstract}
A calix[4]arene host equipped with two bis$\mathrm{Zn}$ (salphen) complexes self-assembles into a capsular complex in the presence of a chiral diamine guest with an unexpected 2:1 ratio between the host and the guest. Effective chirality transfer from the diamine to the calix-salen hybrid host is observed by $C D$ spectroscopy, and a high stability constant $K_{21}$ of 1.59 $\times 10^{11} \mathrm{M}^{-2}$ for the assembled host-guest ensemble has been determined with a substantial cooperativity factor $a$ of 6.4. DFT analysis has been used to investigate the origin of the stability of the host-guest system and the experimental CD spectrum compared with the calculated ones for both possible diastereoisomers showing that the $M, M$-isomer is the one that is preferentially formed. The current system holds promise for the chirality determination of diamines as evidenced by the investigated substrate scope and the linear relationship between the ee of the diamine and the amplitude of the observed Cotton effects.
\end{abstract}

\section{Introduction}

The creation and transfer of chirality, sometimes

[a] L. Martínez, Dr. N. A. G. Bandeira, Prof. Dr. C. Bo, Prof. Dr. A. W. Kleij, Institute of Chemical Research of Catalonia (ICIQ), Av. Països Catalans 16, 43007 Tarragona, Spain

E-mail: akleij@iciq.es

[b] Prof. Dr. C. Bo

Departament de Química Física i Inorgànica, Universitat Rovira i

Virgili, Marcel-lí Domingo s/n, 43007 Tarragona, Spain

[c] Prof. Dr. A. W. Kleij

Catalan Institute of Research and Advanced Studies (ICREA), Pg. Lluís Companys 23, 08010 Barcelona, Spain

Supporting information for this article is given via a link at the end of the document referred to as chirogenesis, plays a key role in biological processes that involve proteins and other natural systems such as DNA. ${ }^{[1]}$ Chiral transmission has also been shown to be crucial in the catalytic asymmetric synthesis of various organic compounds, where a metal or organic catalyst favors the formation of one preferred chiral product in the enantiocontrolling step. ${ }^{[2]}$ Further to this, to date highly efficient methodologies have been designed to create materials with reversible and responsive features, and smart materials have also been developed with predesigned sensing purposes. ${ }^{[3]}$ The field of chirality sensing has rapidly advanced over the last five years with a strong focus on newly designed systems that may facilitate fast and efficient determination of the concentration, absolute configuration, enantiomeric excess and/or molecular identity of a chiral analyte. ${ }^{\text {[4] }}$ Whereas bis-porphyrins have been and still continue to be popular hosts in chirality transfer processes, ${ }^{[4,5]}$ we have recently started to use modular and easy to assemble dinuclear and trinuclear $\mathrm{Zn}$ (salen) based hosts that show (strong) chirogenesis effects in the presence of chiral carboxylic acids, ${ }^{[4 d]}$ diamines, aminoalcohols and diols ${ }^{[6]}$ induced by $1: 1$ complex formation between the host and the guest.

With most reported supramolecular host systems, the transfer of chiral information by interaction with chiral diamines is hampered by the requirement of a pre-treatment of the analyte with additives, the use of a (large) excess of diamine, the requirement of airsensitive reagents and/or a relatively low binding 
constants between the host and guest partners; such challenges makes the quest for an efficient host system still an important undertaking.

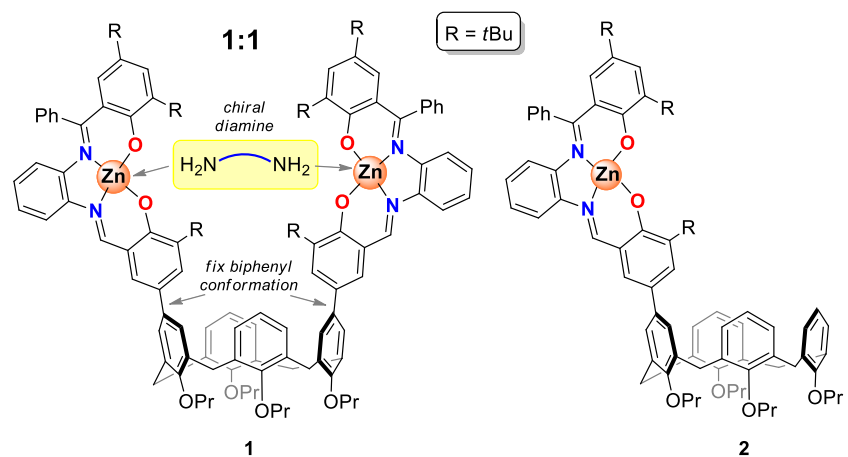

Scheme 1. Schematic structures of calix-Zn(salphen) hosts $\mathbf{1}$ and $\mathbf{2}$ and the expected coordination stoichiometry (1:1) and induction of chirality in host 1 by binding to a one molecule of a ditopic chiral diamine.

Here, we present a new type of supramolecular host for chiral diamine guests that is based on a calix[4]arene-salen hybrid structure. Each calixarene unit is functionalized by two distal $\mathrm{Zn}$ (salphen) complexes connected to the upper rim of the calixarene incorporating two pro-chiral biphenyl units (Scheme 1; host 1). These Zn(salphen) complexes are known to form stable complexes with amine donors ${ }^{[7]}$ and as such we anticipated the easy formation of 1:1 complexes with chiral diamines; i.e., complex 1 would thus be engaged with one diamine. However, the unusual formation of 2:1 host/guest assemblies with two molecules of calixarene-bis-Zn(salphen)s are interacting with only one diamine was noted with concomitant, cooperative and diastereo-selective encapsulation of the chiral diamine guest. The underlying reasons for this unusual observation have been investigated in detail using various experimental and computational methods, and the use of these types of calix-salen host systems in the determination of the absolute configuration and ee of the diamine is also detailed. 


\section{Results and Discussion}

We first designed host 1 (Scheme 2 and Schemes S1S2; Supporting Information for more details; Figures S1-16) having two co-facially orientated $\mathrm{Zn}$ (salphen) units that should accommodate the binding of suitable chiral diamine guests and block the $\mathrm{C}_{\text {ary }}-\mathrm{C}_{\text {aryl }}$ rotation of the biphenyl units leading to chirality transfer effects.

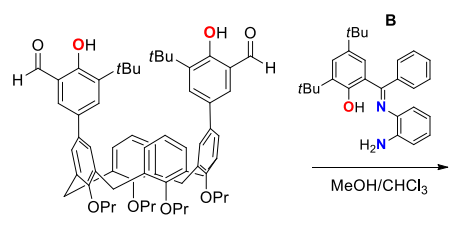

A-1

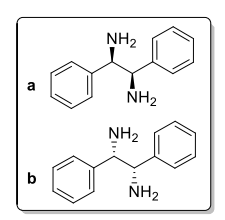

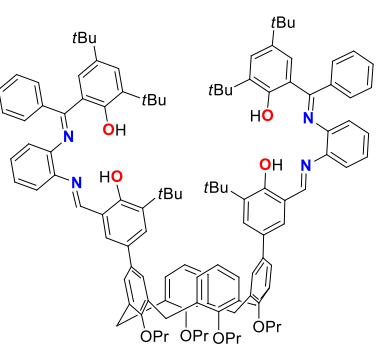

B-1 $\mid \mathrm{ZnEt}_{2}$

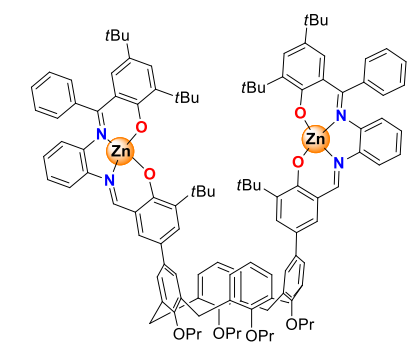

1
Scheme 2. Synthesis of bis-Zn(salphen) host 1 and schematic structures for chiral diamines $\mathbf{a}$ and $\mathbf{b}$.

The synthesis of host 1 started off by using known calixarene-disalicylaldehyde A-1 and treatment with the ketamine reagent $\mathbf{B}$ (Scheme S1) furnishing the calixarene-bis-salphen ligand $\mathbf{B}-\mathbf{1}$ in $\mathbf{7 0 \%}$ yield. The $\mathbf{Z n}$ based host $\mathbf{1}$ was then prepared from $\mathbf{B}-\mathbf{1}$ by reaction with a stoichiometric amount of $\mathrm{ZnEt}_{2}$ in THF giving the desired calixarene-bis- $\mathrm{Zn}$ (salphen) complex in $83 \%$ yield. Likewise, the mono-Zn host 2 (Scheme S2) was prepared in a similar way in $99 \%$ yield from its calixarene-mono-salphen precursors. Complex $\mathbf{2}$ represents a control compound in the chirality transfer experiments as will be discussed below.

The potential induction of chirality by chiral diamines and thus a conformational control within host structure 1 was first probed in the presence of $(1 R, 2 R)-(+)-1,2$-diphenylethylenediamine a (Scheme 2) and the UV-vis and circular dichroism (CD) features of 1 in the presence of this chiral diamine were studied. Titration of a solution of $1\left(\mathrm{CH}_{2} \mathrm{Cl}_{2} ; 6 \times 10^{-5} \mathrm{M}\right)$ with a solution of the diamine a $\left(\mathrm{CH}_{2} \mathrm{Cl}_{2} ; 6 \times 10^{-4} \mathrm{M}\right)$ showed typical UV-vis changes of a $\mathrm{Zn}$ (salphen) derived complex (Figure 1a). A small but detectable bathochromic shift ( $D /=6 \mathrm{~nm}$ ) was noted together with a significant decrease of the absorption upon addition of higher amounts of diamine a. Similar types of bathochromic shifts of $\mathrm{Zn}$ (salphen)s were noted in the presence of pyridine donors, ${ }^{[8]}$ however in these cases an increasing absorption was noted at higher concentrations of analyte due to aggregate-tomonomer transitions of these materials. Thus, in the present case it seems that host molecule 1 does not seem to be in an aggregated state rendering it useful for interaction with suitable ditopic substrates such as diamine $a$. The $C D$ features of (Figures $1 b$ and $1 d$ ) 1 showed typical Cotton effects at $I=416$ and $476 \mathrm{~nm}$ with an unexpected saturation point after the addition of 0.5 equiv of diamine a, i.e. at a $2: 1$ hostguest ratio (Figure 1c). ${ }^{[9]}$ The species formed at this ratio proved to be rather stable as a large excess of 40 equiv of the diamine guest are required to fully disrupt the 2:1 assembly (Supporting Information; Figure S28). 
(a)

(b)

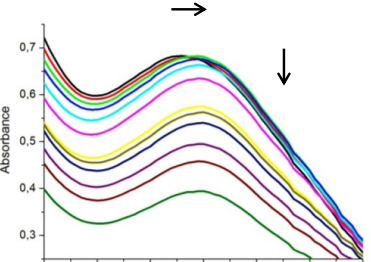

(c)
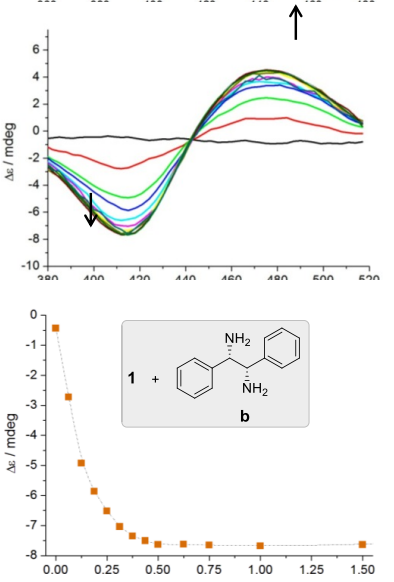

(d)
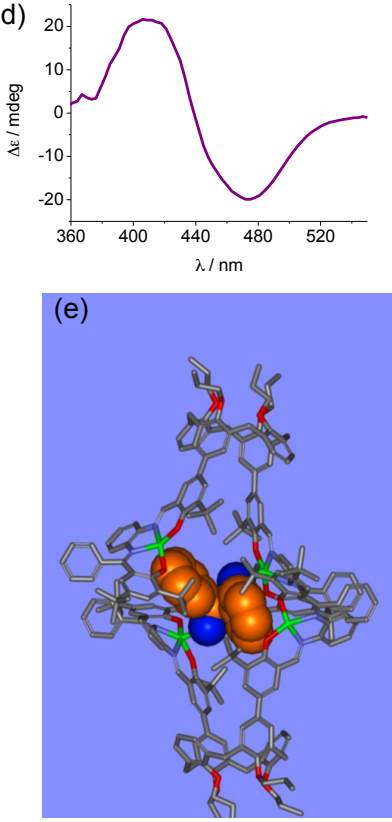

Figure 1. a) Zoom of the UV-vis spectrum for $1(6 \times 10$ ${ }^{5} \mathrm{M} ; \mathrm{CH}_{2} \mathrm{Cl}_{2}$ ) in the presence of increasing amounts of diamine a (0-100 eq). b) CD spectral changes for host $1\left(6 \times 10^{-5} \mathrm{M} ; \mathrm{CH}_{2} \mathrm{Cl}_{2}\right)$ in the presence of $0.06-1.50$ equiv of diamine b. c) Titration curve for 1 using the $C D$ data at $I=416 \mathrm{~nm}$. d) $C D$ response for 1 in the presence of 0.5 equiv of diamine a at $[\mathbf{1}]=2 \times 10^{-4} \mathrm{M}$ $\left(\mathrm{CH}_{2} \mathrm{Cl}_{2}\right)$. e) Computed structure for assembly $(\mathbf{1})_{2} \cdot \mathbf{b}$.

The binding constant $K_{2,1}$ represents the binding of one diamine with two equiv of calixarene host 1 ; if this binding process is cooperative (i.e., $K_{1,1}<K_{1,1-2,1}$ ) then $K_{2,1}=\mathrm{a} K_{\mathrm{M}}^{2}$ where $\mathrm{a}$ is the cooperativity factor and $K_{\mathrm{M}}$ represents the microscopic binding constant. The $K_{\mathrm{M}}$ value can be derived from the equation $K_{1,1}=$ $2 K_{\mathrm{M}}$ with two possible and identical binding sites for the amine. To evaluate possible cooperative effects in the formation of $(\mathbf{1})_{2} \cdot \mathbf{a}$, we first determined $K_{1,1}$ by titration of model complex $\mathbf{2}$ (Scheme 1) with benzylamine, giving a value of $3.14 \times 10^{5} \mathrm{M}^{-1}$. The binding constant $K_{2,1}$ was hereafter determined using fluorescence titration data of $\mathbf{1}$ in the presence of diamine $\mathbf{a}$ and was found to be very high $(1.59 \pm 0.14$ $\times 10^{11} \mathrm{M}^{-2}$ ) with an a of 6.4 in line with a strong,

cooperative binding of a (full details in the Supporting Information). Interestingly, a similar preferred 2:1 stoichiometry between host $\mathbf{1}$ and diamines $\mathbf{b}$ and $\mathbf{d}$ (Figures S29-S32) was found as evidenced by their titration data, thus pointing to more general and similar chirality transfer behaviour for $\mathbf{1}$ in the presence of chiral diamines.

In order to understand in more detail the binding mode in $(\mathbf{1})_{2} \cdot \mathbf{b}$, a number of additional experiments were conducted. Structures for both the 1:1 as well as 2:1 assemblies based on $\mathbf{1}$ and diamine $\mathbf{b}$ were generated and fully optimized using a ONIOM QM/QM strategy (see also Supporting Information for details and Figure 1e). Interestingly, the 1:1 hostguest complex shows a higher degree of distortion within each $\mathrm{Zn}$ (salphen) unit as a consequence of the ditopic binding of diamine $\mathbf{b}$. In the 2:1 model, this effect is less pronounced showing this system to be of significantly lower energy ( -36.3 versus -27.4 $\mathrm{kcal} / \mathrm{mol}$; Figures S38 and S39). Further to this, in the 2:1 system (see Figure 1e) two key features are observed. The first one is the presence of multiple $p-p$ stacking interactions (virtually absent in the 1:1 complex; Figure S40) between the phenyl groups of the guest with the phenyl groups of the coordinated $\mathrm{Zn}$ (salphen) units of two calix[4]arene-bis-Zn(salphen) help to stabilize the assembled 2:1 complex. In line with this observation is the significant ${ }^{1} \mathrm{H}$ NMR upfield shift noted for the imine-H of host $\mathbf{1}$ in the presence of diamine guest a $\left(\left[D_{6}\right]\right.$ acetone $) ;{ }^{[10]}$ where as for the free host 1 this resonance is located at $9.09 \mathrm{ppm}$, in the presence of $\mathbf{a}$ it is shifted to $8.64 \mathrm{ppm}$ ( $\mathrm{D} d=-0.45$ ppm; for completion the calixarene bis-ligand B-1 shows a resonance at $8.80 \mathrm{ppm})$. Such an upfield shift is much larger than has been previously found for pyridine coordination to $\mathrm{Zn}$ (salphen)s which typically results in very small shifts for the imine- $\mathrm{H}^{\left[{ }^{[8]}\right]}$ Therefore it seems reasonable to suggest that the imine- $\mathrm{H}$ in $\mathbf{1}$ are affected by the encapsulation process and are located nearby the pi-surface of the diamine guest a (Figures S40 and S42). 


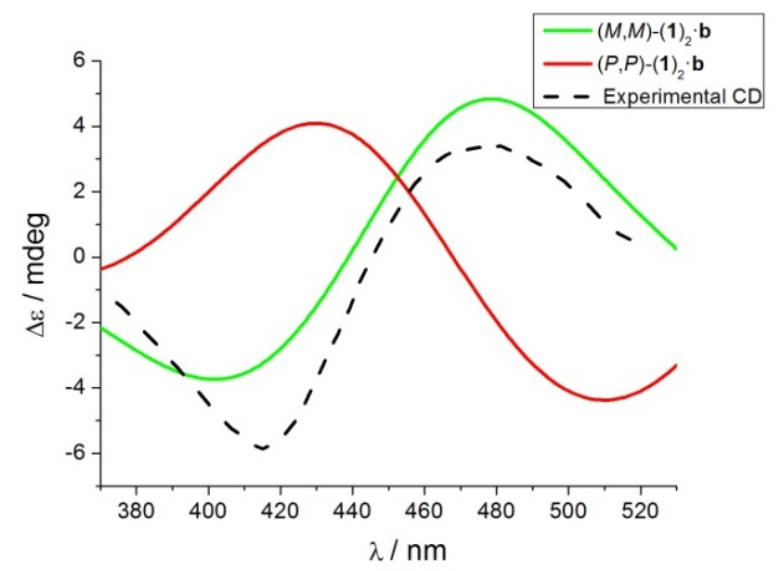

Figure 2. Comparison between the computed CD spectra for diastereo-isomeric assemblies $(P, P)-(\mathbf{1})_{2} \cdot \mathbf{b}$ (red trace) and $(M, M)-(\mathbf{1})_{2} \cdot \mathbf{b}$ (green trace) and the experimental observed one (dashed curve).

The second remarkable feature is the conformation of the two non-coordinated $\mathrm{Zn}$ (salphen) units [one present in each calix[4]arene-bis-Zn(salphen)], which shows some degree of distortion of the $\mathrm{N}_{2} \mathrm{O}_{2}$ tetradentate coordination plane of the salphen ligand with the Zn ion pushed "inwards" (Figure S41). As a result, these non-coordinated $\mathrm{Zn}$ (salphen)s units are sterically congested and not easily approachable for incoming ligands (cf., diamines such as b). Both features (Figures S40 and S41) support the high stability found for the 2:1 assembly, and the coordination of the diamine $\mathbf{b}$ to two molecules of $\mathbf{1}$ results in the cooperative and full encapsulation of the diamine guest.

Table 1. Collected CD data for host 1 in the presence of various chiral ditopic ligands a-l. ${ }^{[\mathrm{a}]}$

\begin{tabular}{|c|c|c|c|}
\hline Diamine guest & $l[\mathrm{~nm}]$ & $\begin{array}{l}\mathrm{De}\left[\mathrm{M}^{-1} \cdot \mathrm{cm}^{-}\right. \\
\left.{ }_{1}^{1}\right]^{[\mathrm{b}][\mathrm{c}]}\end{array}$ & $\begin{array}{l}\mathrm{D} e\left[\mathrm{M}^{-1} \cdot \mathrm{cm}^{-}\right. \\
\left.{ }_{1}^{1}\right]^{[\mathrm{b}] \mathrm{cc}]}\end{array}$ \\
\hline \multirow[t]{2}{*}{$\overline{\mathbf{a}}$} & 416 & 5.6 & 21 \\
\hline & 476 & -6.4 & -20 \\
\hline \multirow[t]{2}{*}{ b } & 416 & -5.4 & -23 \\
\hline & 476 & 6.6 & 20 \\
\hline \multirow[t]{2}{*}{ c } & 420 & -3.2 & -6.6 \\
\hline & 484 & 1.2 & 1.8 \\
\hline \multirow[t]{2}{*}{ d } & 426 & -4.0 & -15 \\
\hline & 475 & 0.3 & 4.7 \\
\hline \multirow[t]{2}{*}{$\mathbf{e}$} & 413 & -9.5 & -13 \\
\hline & 476 & 6.3 & 14 \\
\hline \multirow[t]{2}{*}{ f } & 424 & -6.4 & 26 \\
\hline & 481 & 3.0 & 24 \\
\hline \multirow[t]{2}{*}{ g } & 424 & -1.8 & -6.1 \\
\hline & 480 & 0 & 2.0 \\
\hline \multirow[t]{2}{*}{ h } & 420 & -2.3 & -3.6 \\
\hline & 480 & 0 & 0.7 \\
\hline$i-1$ & - & 0 & 0 \\
\hline \multicolumn{4}{|c|}{$\begin{array}{l}\text { [a] Measured in } \mathrm{CH}_{2} \mathrm{Cl}_{2} \text { at }[\mathbf{1}]=6 \times 10^{-5} \mathrm{M} \text {. [b] The DA } \\
\text { values are } \mathrm{D} e / 32982 \text {. [c] Data refer to the CD output at }[\mathbf{1}]= \\
2 \times 10^{-4} \mathrm{M} \text {. Note that for potentially ditopic substrates } \mathbf{i}-\mathrm{l} \text { no } \\
\text { output was observed at either concentration of } \mathbf{1} \text { except for } \mathbf{j} \\
\left(\mathrm{D} e=13.0 \mathrm{M}^{-1} \cdot \mathrm{cm}^{-1} \text { at } l=464 \mathrm{~nm} \text { ). For representative CD }\right. \\
\text { spectra see Figures } 1 \mathrm{~d} \text { and } 2 \text {; see also Supporting }\end{array}$} \\
\hline
\end{tabular}


Information.

${ }^{1} \mathrm{H}$ DOSY NMR $\left(\mathrm{CD}_{2} \mathrm{Cl}_{2}\right.$; Figure $\left.\mathrm{S} 43\right)$ analysis was also carried out providing a molecular radius of $11.0 \AA$ which is close to the estimated one (11.4 $\AA$ ) derived from the computed structure for assembly $(\mathbf{1})_{2} \cdot \mathbf{b}$ by DFT (Figure S39; Supporting Information). Since the $\mathrm{CD}$ results for $(\mathbf{1})_{2} \cdot \mathbf{b}$ point to a clear transfer of chirality from the diamine to the host, the $C D$ traces of both possible $(M, M)$ and $(P, P)$ configured diastereoisomers were calculated by DFT methods. ${ }^{[11]}$ The calculated $C D$ spectrum for $(M, M)-(\mathbf{1})_{2} \cdot \mathbf{b}$ showed a remarkable resemblance with the experimental one, suggesting that this diastereoisomer should be the predominant species observed in solution (Figure 2). The large resemblance of the experimental and calculated CD traces for the 2:1 assembly $(\mathbf{1})_{2} \cdot \mathbf{a}$ is further support for a selective encapsulation process.

In order to further investigate the scope, a series of other (potentially) ditopic substrates (Table $1 ; \mathbf{b}$-I) were then combined with host 1 and their CD spectra recorded. ${ }^{[12]}$ As expected, $(1 S, 2 S)-(-)-1,2-$ diphenylethylenediamine $\mathbf{b}$ showed opposite Cotton effects compared to diamine a. Other diamine substrates having a $(1 S, 2 S)$ configuration $(\mathbf{c}-\mathbf{f})$ showed similar Cotton effects as $\mathbf{b}$ suggesting that host $\mathbf{1}$ could be useful to determine the absolute configurations of chiral diamines. Interestingly, when chiral diamines $\mathbf{g}$ and $\mathbf{h}$ (having only one chiral centre) were used, similar CD behaviour was noted as observed for $\mathbf{b}-\mathbf{f}$, and therefore the presence of only one chiral centre in the diamine substrate seems to be required for effective chirality transmission. A more rigid diamine such as $\mathbf{i}$ did not lead to any observable chirality transfer; apparently, the rigidity of this diamine does not allow for productive diamine complexation as noted for $\mathbf{a}-\mathbf{h}$. The absence of any $C D$ signals in the presence of ditopic systems $\mathbf{j}-\mathbf{k}$ (at $[1]=6 \times 10^{-5} \mathrm{M}$ ) emphasizes the requirement of the presence of two (electron-rich) $\mathrm{N}$-donor atoms in the guest structure. The fact that O-donor based aminoalcohol $\mathbf{j}$, amide-based $\mathbf{k}$ and diol I did not produce any useful CD output is in line with previous work on the coordination behaviour of $\mathrm{Zn}$ (salphen)s that (strongly) prefer $\mathrm{N}$-donor over alcohol ligands. ${ }^{[13]}$ Finally, various ratios of $\mathbf{a}$ and $\mathbf{b}$ in the presence of host 1 were then analysed by CD spectroscopy and the amplitude of the Cotton effects compared with the actual ee's of the diamine samples (Supporting Information). A linear dependence was found and the calibration showed low absolute errors in the ee determinations (around 1\%), a feature potentially useful for practical applications as detection by $\mathrm{CD} /$ fluorescence spectroscopy allows for very low concentrations $\left(10^{-5}\right.$ to $\left.10^{-6} \mathrm{M}\right)$ of diamine to be determined.

\section{Conclusions}

In summary, we here present a unique self-assembled host-guest system with an unexpected binding motif between the host and the guest. Two molecules of 1 bind one diamine guest to form an encapsulated system with effective chirality transfer from guest to the host as supported by CD experiments. The high stability of this new host-guest system prospectively allows for the determination of low concentrations of chiral diamines, their absolute configuration and their enantiomeric excess.

\section{Experimental Section}

Gereral methods and materials: Compound $\mathbf{A}-\mathbf{1}^{[14]}$ mono-5-bromo-tetrapropoxycalix[4]arene, ${ }^{[15]} 3$-(tertbutyl)-2-hydroxy-5-(4,4,5,5-tetra-methyl-1,3,2dioxaborolan-2-yl)benzaldehyde, ${ }^{[16]}(S)$-1phenylethane-1,2-diamine, ${ }^{[17]}$ and (S)-2-amino-2phenylacetamine ${ }^{[18]}$ were prepared as reported previously. All others chemicals are commercial available in Aldrich and used as received. ${ }^{1} \mathrm{H}$ NMR and ${ }^{13} \mathrm{C}$ NMR spectra were recorded on Bruker Avance 500 NMR spectrometers at $297 \mathrm{~K}$. Chemical shifts are reported in ppm relative to the residual solvent peaks 
in $\mathrm{CDCl}_{3}(\delta=7.26 \mathrm{ppm})$ and DMSO- $d_{6}(\delta=2.50 \mathrm{ppm})$. Mass analyses were carried out by the High Resolution Mass Spectrometry Unit at the ICIQ in Tarragona, Spain. Elemental analyses were determined by the Elemental Analysis Unit of the University of Santiago de Compostela, Spain. UV/Vis and $C D$ spectra were recorded on an Applied Photophysics Circular Dichroism Chirascan Spectrophotometer using host 1 at $6 \times 10^{-5} \mathrm{M}$ in DCM, using the following parameters: step-size $2 \mathrm{~nm}$, timeper-point $0.5 \mathrm{~s}, 3$ repeats per sample, $\mathrm{T}=24^{\circ} \mathrm{C}$. Further details are mentioned in each respective section provided below.

\section{Synthesis of precursor (3,5-di-tert-butyl-2-} hydroxyphenyl)(phenyl)-methanone (A): Under an argon atmosphere, 3,5-di-tert-butylsalicylic acid (1.0 $\mathrm{g}, 4 \mathrm{mmol})$ was dissolved in dry THF $(30 \mathrm{ml})$. A phenyllithium solution ( $1.8 \mathrm{M}, 13 \mathrm{ml}, 25 \mathrm{mmol}$ ) was added drop-wise at 0 - $\mathrm{C}$. The solution was then stirred at $10 \circ \mathrm{C}$ for $18 \mathrm{~h}$. Then, freshly distillated $\mathrm{Me}_{3} \mathrm{SiCl}(7$ $\mathrm{ml}, 56 \mathrm{mmol}$ ) was added, and the reaction mixture was stirred for $1 \mathrm{~h}$. Diluted $\mathrm{HCl}(3 \mathrm{M}, 30 \mathrm{ml})$ was then added, and the organic phase was extracted with diethyl ether and the combined extracts dried over $\mathrm{Na}_{2} \mathrm{SO}_{4}$. The product was purified by column chromatography (5/95 up to $10 / 90 \mathrm{v} / \mathrm{v}$ ethyl acetate/hexane) to give a yellow solid. Yield: $92 \% .{ }^{1} \mathrm{H}$ $\operatorname{NMR}\left(500 \mathrm{MHz}, \mathrm{CDCl}_{3}\right): \delta=1.25(\mathrm{~s}, 9 \mathrm{H}), 1.49(\mathrm{~s}, 9 \mathrm{H})$, $7.44(\mathrm{~d}, J=2.4 \mathrm{~Hz}, 2 \mathrm{H}), 7.71-7.48(\mathrm{~m}, 5 \mathrm{H}), 12.71(\mathrm{~s}$, $1 \mathrm{H}) ;{ }^{13} \mathrm{CNMR}\left(125 \mathrm{MHz}, \mathrm{CDCl}_{3}\right): \delta=29.6,31.4,34.4$, 35.4, 118.2, 128.0, 128.3, 129.4, 131.4, 131.7, 138.0, 138.9, 140.0, 160.1, 202.7; HRMS (ESI+, MeOH): calcd $\mathrm{m} / \mathrm{z}$ for $\mathrm{C}_{21} \mathrm{H}_{26} \mathrm{O}_{2} \mathrm{Na:} 333.1825$; found: 333.1828 .

\section{Synthesis of precursor (E)-2-(((2-}

\section{Aminophenyl)imino)-(phenyl)methyl)-4,6-di-tert-} butylphenol (B): Compound A (300 mg, $0.88 \mathrm{mmol}$ ) was dissolved in toluene $(20 \mathrm{ml})$ and $o$ phenylenediamine (191 $\mathrm{mg}, 1.76 \mathrm{mmol}$ ) and $p$ toluenesulfonic acid ( $8 \mathrm{mg}, 0.09 \mathrm{mmol}$ ) was added to the mixture. The reaction was performed using a
Dean-Stark apparatus (120-130ㅇ) for $30 \mathrm{~h}$. Then, the reaction was cooled down and the precipitated solid was filtered off and washed with $\mathrm{MeOH}$ to obtain a yellow solid. Yield: $74 \% .{ }^{1} \mathrm{H} \mathrm{NMR}\left(500 \mathrm{MHz}, \mathrm{CDCl}_{3}\right): \delta=$ $1.15(\mathrm{~s}, 9 \mathrm{H}), 1.51(\mathrm{~s}, 9 \mathrm{H}), 3.84(\mathrm{~s}, 2 \mathrm{H}), 6.27$ (dd, $J=1.5$, $8.0 \mathrm{~Hz}, 1 \mathrm{H}), 6.40(\mathrm{td}, J=1.4 \mathrm{~Hz} ; 7.6 \mathrm{~Hz}, 1 \mathrm{H}), 6.67(\mathrm{dd}, J$ $=1.4 \mathrm{~Hz} ; 8.0 \mathrm{~Hz}, 1 \mathrm{H}), 6.81(\mathrm{td}, J=1.5 \mathrm{~Hz} ; 7.6 \mathrm{~Hz}, 1 \mathrm{H})$, $6.96(\mathrm{~d}, J=2.5 \mathrm{~Hz}, 1 \mathrm{H}), 7.17-7.23(\mathrm{~m}, 2 \mathrm{H}), 7.30-7.34$ $(\mathrm{m}, 3 \mathrm{H}), 7.46(\mathrm{~d}, \mathrm{~J}=2.5 \mathrm{~Hz}, 1 \mathrm{H}), 14.90(\mathrm{~s}, 1 \mathrm{H}) ;{ }^{13} \mathrm{C} \mathrm{NMR}$ (125 MHz, $\mathrm{CDCl}_{3}$ ): $\delta=29.7,31.4,34.3,35.4,115.2$, $118.1,119.0,122.2,125.6,127.0,128.1,128.3,128.5$, 129.1, 134.2, 135.1, 136.7, 137.4, 139.1, 139.4, 159.9, 176.2. HRMS (ESI+, MeOH): calcd $m / z$ for $\mathrm{C}_{27} \mathrm{H}_{33} \mathrm{ON}_{2}$ : 401.2587; found: 401.2584.

\section{Bis-(4,6-di-tert-butylphenol-salphen)calix[4]arene} ligand (B-1): Compounds A-1 (150 mg, $0.16 \mathrm{mmol}$ ) and $\mathbf{B}$ (134 $\mathrm{mg}, 0.33 \mathrm{mmol}$ ) were dissolved in a 50/50 $\mathrm{v} / \mathrm{v} \mathrm{MeOH} / \mathrm{CHCl}_{3}(10 \mathrm{ml})$. The mixture was kept at reflux temperature for $48 \mathrm{~h}$ (until all the aldehyde was consumed as followed by TLC). Then the solvent was evaporated to afford a yellow solid, which was washed and triturated with $\mathrm{MeOH}$. Yield: $70 \% .{ }^{1} \mathrm{H}$ NMR $\left(500 \mathrm{MHz}^{\mathrm{C}} \mathrm{CDCl}_{3}\right): \delta=0.88-1.00(\mathrm{~m}, 12 \mathrm{H}), 1.11$ $(\mathrm{s}, 18 \mathrm{H}), 1.36(\mathrm{~s}, 18 \mathrm{H}), 1.53(\mathrm{~s}, 18 \mathrm{H}), 1.84-2.03(\mathrm{~m}, 8 \mathrm{H})$, $3.23(\mathrm{~d}, J=13.5 \mathrm{~Hz}, 4 \mathrm{H}), 3.66-3.80(\mathrm{~m}, 4 \mathrm{H}), 3.99-4.12$ $(\mathrm{m}, 4 \mathrm{H}), 4.52(\mathrm{~d}, J=13.0 \mathrm{~Hz}, 4 \mathrm{H}), 6.16-6.35(\mathrm{~m}, 8 \mathrm{H})$, 6.86-6.92 (m, 2H), 7.03-7.33 (m, 18H), $7.46(\mathrm{~d}, J=9.5$ $\mathrm{Hz}, 4 \mathrm{H}), 7.63(\mathrm{~s}, 2 \mathrm{H}), 8.53(\mathrm{~s}, 2 \mathrm{H}), 13.88(\mathrm{~s}, 2 \mathrm{H}), 14.70$ (s, 2H). ${ }^{13} \mathrm{CNMR}\left(125 \mathrm{MHz}, \mathrm{CDCl}_{3}\right): \delta=10.0,11.0$, 23.2, 23.7, 29.4, 29.8, 31.1, 31.4, 34.2, 35.2, 35.4, $76.6,77.4,118.4,118.5,119.3,122.3,123.6,125.3$, $126.8,127.0,127.7,128.3,128.4,128.8,129.3,131.2$, 133.2, 134.4, 135.6, 137.4, 138.2, 138.7, 139.5, 142.1, 155.4, 157.4, 160.0, 160.3, 162.8, 176.0. HRMS (ESI+, $\mathrm{MeOH}$ ): calcd $m / z$ for $\mathrm{C}_{116} \mathrm{H}_{133} \mathrm{O}_{8} \mathrm{~N}_{4}: 1710.0118$; found: 1710.0064 .

Bis-(4,6-di-tert-butylphenol-salphen)calix[4]arene
Zinc complex (1): Under an argon atmosphere,
compound B-1 (100 $\mathrm{mg}, 0.059 \mathrm{mmol})$ was dissolved in
dry THF (10 $\mathrm{ml})$, and then a solution of $\mathrm{ZnEt}_{2}(1 \mathrm{M}, 0.12$ 
$\mathrm{ml}, 0.118 \mathrm{mmol}$ ) was added drop-wise and the reaction mixture was stirred for $4 \mathrm{~h}$. Then, the solvent was evaporated to afford a bright orange solid. Yield: 83\%. ${ }^{1} \mathrm{H}$ NMR (500 MHz, DMSO): $\delta=0.91(\mathrm{t}, J=7.5 \mathrm{~Hz}$, $6 \mathrm{H}), 1.02(\mathrm{~s}, 18 \mathrm{H}), 1.09-1.15(\mathrm{~m}, 24 \mathrm{H}), 1.45(\mathrm{~s}, 18 \mathrm{H})$, 1.83-1.90 (m, 4H), 1.95-2.03 (m, 4H), 3.22-3.26 (m, $4 \mathrm{H}), 3.62-3.68(\mathrm{~m}, 4 \mathrm{H}), 4.01-4.07(\mathrm{~m}, 4 \mathrm{H}), 4.38-4.45$ $(\mathrm{m}, 4 \mathrm{H}), 4.94(\mathrm{~s}, 4 \mathrm{H}), 6.21-6.28(\mathrm{~m}, 8 \mathrm{H}), 6.33(\mathrm{~d}, J=6.7$ $\mathrm{Hz}, 2 \mathrm{H}), 6.48$ (d, J = 7.9 Hz, 2H), 6.57-6.81 (m, 4H), $7.07(\mathrm{t}, J=8.0 \mathrm{~Hz}, 2 \mathrm{H}), 7.23-7.28(\mathrm{~m}, 4 \mathrm{H}), 7.37-7.45$ $(\mathrm{m}, 10 \mathrm{H}), 7.56-7.69(\mathrm{~m}, 4 \mathrm{H}), 9.04(\mathrm{~s}, 2 \mathrm{H}) ;{ }^{13} \mathrm{C}$ NMR $(125$ MHz, DMSO): $\delta=10.0,11.0,22.8,23.3,29.6,29.8$, $30.3,31.3$, 33.6, 35.0, 35.3, 35.6, 76.1, 77.0, 114.7, $115.9,119.1,119.7,121.9,125.5,126.0,126.4,127.3$, 127.6, 128.0, 128.2, 128.5, 129.0, 132.0, 132.9, 134.9, $136.5,136.8,140.2,140.3,140.7,141.2,141.7,155.0$, 156.0, 159.6, 162.9, 170.1, 171.4, 174.2, 175.8; HRMS (MALDI+, dctb): calcd $m / z$ for $\mathrm{C}_{116} \mathrm{H}_{130} \mathrm{O}_{8} \mathrm{~N}_{4} \mathrm{Zn}_{2}$ $(\mathrm{M}+2 \mathrm{H})^{+}:$1836.8628; found: 1836.8772 .

\section{5-Mono-[1-(3-tert-butyl-2-hydroxy-1-formylphenyl)]-} 25,26,27,26-tetra-propoxy-calix[4]arene (B-2): Under an argon atmosphere, $\mathrm{Pd}(\mathrm{OAc})_{2}$ (10 $\left.\mathrm{mg}, 0.045 \mathrm{mmol}\right)$ and $\mathrm{P}(\mathrm{o} \text {-tol })_{3}(27 \mathrm{mg}, 0.089 \mathrm{mmol})$ were dissolved in previously deoxygenated toluene $(25 \mathrm{ml})$. After stirring the mixture for $30 \mathrm{~min}$, mono-5-bromotetrapropoxycalix[4]arene $(500 \mathrm{mg}, 0.74 \mathrm{mmol})^{[15]}$ and 3-(tert-butyl)-2-hydroxy-5-(4,4,5,5-tetramethyl1,3,2-dioxaborolan-2-yl)-benzaldehyde (268 mg, 0.89 $\mathrm{mmol})^{[16]}$ were dissolved in deoxygenated $\mathrm{MeOH}(5$ $\mathrm{ml}$ ) and added to the mixture with an aqueous solution of $\mathrm{K}_{2} \mathrm{CO}_{3}(2 \mathrm{M}, 5 \mathrm{~mL})$. After $40 \mathrm{~h}$ stirring at 65응 $C$, the reaction mixture was cooled down and water $(10 \mathrm{~mL})$ and $\mathrm{HCl}(1 \mathrm{M}, 5 \mathrm{~mL})$ were added. The crude product was filtered through Celite and extracted three times with ethyl acetate. The organic phases were combined and dried over $\mathrm{Na}_{2} \mathrm{SO}_{4}$. The solvent was evaporated and the white solid obtained further triturated with $\mathrm{MeOH}$. Yield: 71\%. ${ }^{1} \mathrm{H}$ NMR $(500 \mathrm{MHz}$, $\left.\mathrm{CDCl}_{3}\right): \delta=0.95(\mathrm{t}, J=7.4 \mathrm{~Hz}, 6 \mathrm{H}), 1.04(\mathrm{t}, J=7.4 \mathrm{~Hz}$, $3 \mathrm{H}), 1.07(\mathrm{t}, J=7.4 \mathrm{~Hz}, 3 \mathrm{H}), 1.40(\mathrm{~s}, 9 \mathrm{H}), 1.86-2.01(\mathrm{~m}$, $8 \mathrm{H}), 3.15(\mathrm{~d}, J=13.4 \mathrm{~Hz}, 2 \mathrm{H}), 3.20(\mathrm{~d}, J=13.4 \mathrm{~Hz}, 2 \mathrm{H})$, $3.76(\mathrm{t}, J=7.1 \mathrm{~Hz}, 2 \mathrm{H}), 3.81(\mathrm{t}, J=7.1 \mathrm{~Hz}, 2 \mathrm{H}), 3.91-$ $3.98(\mathrm{~m}, 4 \mathrm{H}), 4.46(\mathrm{~d}, J=13.4 \mathrm{~Hz}, 2 \mathrm{H}), 4.50(\mathrm{~d}, J=13.4$ $\mathrm{Hz}, 2 \mathrm{H}), 6.06(\mathrm{t}, J=7.5 \mathrm{~Hz}, 1 \mathrm{H}), 6.31(\mathrm{~d}, J=7.5 \mathrm{~Hz}, 2 \mathrm{H})$ $6.51(\mathrm{~s}, 2 \mathrm{H}), 6.74(\mathrm{t}, J=7.5 \mathrm{~Hz}, 2 \mathrm{H}), 6.85(\mathrm{~d}, J=7.5 \mathrm{~Hz}$, $2 \mathrm{H}), 6.89(\mathrm{~d}, J=7.5 \mathrm{~Hz}, 2 \mathrm{H}), 7.22(\mathrm{~d}, J=7.5 \mathrm{~Hz}, 2 \mathrm{H})$, 9.86 (s, 1H), 11.65 (s. $1 \mathrm{H}) ;{ }^{13} \mathrm{C}$ NMR (125 MHz, $\left.\mathrm{CDCl}_{3}\right)$ : $\delta=10.3,10.7,23.3,23.5,23.6,29.4,29.8,31.1,31.3$, $35.0,77.0,77.1,77.4,120.6,121.8,122.0,126.2$, 127.7, 128.7, 128.8, 129.7, 132.9, 133.4, 133.7, 134.4, 134.9, 136.0, 136.3, 138.0, 155.8, 156.1, 157.4, 160.0, 197.5; HRMS (ESI+, MeOH): calcd $m / z$ for $\mathrm{C}_{51} \mathrm{H}_{60} \mathrm{O}_{6} \mathrm{Na}$ : 791.4282; found: 791.4281 .

\section{5-Mono-(4,6-di-tert-butylphenol-}

salphen)calix[4]arene ligand (C-2): Compounds B-2 (100 mg, $0.13 \mathrm{mmol}$ ) and $\mathbf{B}$ (78 $\mathrm{mg}, 0.20 \mathrm{mmol}$ ) were dissolved in a $1: 1 \mathrm{v} / \mathrm{v} \mathrm{MeOH} / \mathrm{CHCl}_{3}(5 \mathrm{ml})$. The mixture was stirred and kept at reflux temperature for $30 \mathrm{~h}$, and showed then full consumption of the aldehyde reagent by TLC. Then the solvent was evaporated to afford a yellow solid, which was triturated with $\mathrm{MeOH}$. Yield: $62 \%$. ${ }^{1} \mathrm{H}$ NMR $\left(500 \mathrm{MHz} \mathrm{CDCl}_{3}\right): \delta=0.96$ (t, $J=7.4 \mathrm{~Hz}, 6 \mathrm{H}), 1.01-1.06(\mathrm{~m}, 6 \mathrm{H}), 1.09(\mathrm{~s}, 9 \mathrm{H}), 1.27$ $(\mathrm{s}, 9 \mathrm{H}), 1.51(\mathrm{~s}, 9 \mathrm{H}), 1.86-1.98(\mathrm{~m}, 8 \mathrm{H}), 3.17(\mathrm{dd}, J=6.7$ $\mathrm{Hz} ; 13.5 \mathrm{~Hz}, 4 \mathrm{H}), 3.78(\mathrm{t}, J=7.3 \mathrm{~Hz}, 2 \mathrm{H}), 3.83(\mathrm{t}, J=7.3$ $\mathrm{Hz}, 2 \mathrm{H}), 3.92(\mathrm{t}, J=7.5 \mathrm{~Hz}, 4 \mathrm{H}), 4.47(\mathrm{t}, J=13.5 \mathrm{~Hz}$, $4 \mathrm{H}), 6.15(\mathrm{t}, J=7.5 \mathrm{~Hz}, 1 \mathrm{H}), 6.38(\mathrm{~d}, J=7.5 \mathrm{~Hz}, 2 \mathrm{H})$, $6.58(\mathrm{~s}, 2 \mathrm{H}), 6.69(\mathrm{t}, J=7.5 \mathrm{~Hz}, 2 \mathrm{H}), 6.76-6.91(\mathrm{~m}, 6 \mathrm{H})$, 7.00-7.13 (m, 8H), $7.20(\mathrm{t}, J=7.3 \mathrm{~Hz}, 2 \mathrm{H}), 7.42(\mathrm{~d}, J=$ $2.3 \mathrm{~Hz}, 1 \mathrm{H}), 8.31(\mathrm{~s}, 1 \mathrm{H}), 13.72(\mathrm{~s}, 1 \mathrm{H}), 16.64(\mathrm{~s}, 1 \mathrm{H})$; ${ }^{13} \mathrm{C} \mathrm{NMR}\left(125 \mathrm{MHz} \mathrm{CDCl}_{3}\right): d=10.3,10.6,10.7,23.3$, 23.5, 23.6, 29.3, 29.8, 31.1, 31.3, 31.4, 34.1, 35.0, $35.4,118.2,118.5,119.1,122.0,123.6,125.2,126.3$, 126.7, 127.6, 128.8, 128.2, 128.6, 128.7, 128.8, 128.9, $129.6,131.5,134.5,134.6,134.9,135.6,135.8,136.0$, 137.4, 137.6, 138.7, 139.6, 142.1, 155.6, 156.2, 157.3, 159.7, 160.2, 162.8, 175.9; HRMS (ESI+, MeOH): calcd $\mathrm{m} / \mathrm{z}$ for $\mathrm{C}_{78} \mathrm{H}_{91} \mathrm{~N}_{2} \mathrm{O}_{6}$ : 1151.6872; found: 1151.6850 .

\section{5-Mono-(4,6-di-tert-butylphenol-}

salphen)calix[4]arene Zinc complex (2): Under an argon atmosphere, precursor compound C-2 (100 mg, 
$0.086 \mathrm{mmol})$ was dissolved in dry THF $(10 \mathrm{ml})$ and then a solution of $\mathrm{ZnEt}_{2}(1 \mathrm{M}, 0.09 \mathrm{ml}, 0.09 \mathrm{mmol})$ was added drop-wise, and the mixture was further stirred for $4 \mathrm{~h}$. The solvent was evaporated to afford a bright orange solid. Yield: $99 \% .{ }^{1} \mathrm{H}$ NMR (500 MHz, DMSO): $\delta$ $=0.96(\mathrm{t}, J=7.5 \mathrm{~Hz}, 6 \mathrm{H}), 0.99-1.05(\mathrm{~m}, 15 \mathrm{H}), 1.39(\mathrm{~s}$, $9 \mathrm{H}), 1.52(\mathrm{~s}, 9 \mathrm{H}), 1.87(\mathrm{dt}, J=7.3 \mathrm{~Hz} ; 14.3 \mathrm{~Hz}, 8 \mathrm{H})$, 3.14-3.24 (m, 4H), 3.70-3.88 (m, 4H), 4.30-4.42 (m, $4 \mathrm{H}), 6.04(\mathrm{t}, J=7.7 \mathrm{~Hz}, 1 \mathrm{H}), 6.33(\mathrm{~d}, J=7.5 \mathrm{~Hz}, 2 \mathrm{H})$, $6.57(\mathrm{~s}, 2 \mathrm{H}), 6.68(\mathrm{t}, J=7.3 \mathrm{~Hz}, 2 \mathrm{H}), 6.76-6.88(\mathrm{~m}, 6 \mathrm{H})$, $6.96(\mathrm{~s}, 1 \mathrm{H}), 7.03-7.42(\mathrm{~m}, 14 \mathrm{H}), 8.88(\mathrm{~s}, 1 \mathrm{H}) ;{ }^{13} \mathrm{C} \mathrm{NMR}$ (125 MHz, DMSO): $d=10.2,10.4,10.5,22.8,22.9$, 23.0, 29.4, 29.5, 29.7, 30.2, 30.4, 30.7, 31.0, 31.1, 33.5, 34.6, 34.9, 35.0, 35.4, 76.3, 116.4, 118.9, 119.1, $121.5,121.6,121.8,124.6,124.7,125.2,125.3,125.7$, $126.5,127.5,128.0,128.2,128.3,128.9,129.7,131.3$, $131.8,134.2,134.4,134.6,135.1,136.2,137.8,139.9$, 140.0, 141.0, 154.3, 155.8, 155.9, 156.3, 156.6, 162.6, 170.9, 171.0, 174.0; HRMS (MALDI+, dctb): calcd m/z for $\mathrm{C}_{78} \mathrm{H}_{88} \mathrm{~N}_{2} \mathrm{O}_{6} \mathrm{Zn}: 1212.5934$; found: 1212.5929 .

Titration studies: To determinate $\boldsymbol{K}_{\mathrm{m}}$, a UV-vis titration was done using a mono-Zn(salphen) calix[4]arene complex (i.e. 2; Scheme 1) as a reference and benzylamine as the titrant (see Supporting Information for more details). The titration data was imported to SPECFIT/32 ${ }^{[19]}$ and the association constant $\boldsymbol{K}_{\mathrm{m}}$ was thus determined. Fluorescence spectra were also recorded (to determine $\boldsymbol{K}_{21}$ ) by using a Fluorolog Horiba Jobin Yvon Spectrophotometer. To get the fluorescence spectra of compound 1, the used /(excitation) was $416 \mathrm{~nm}$. This titration data was imported to SPECFIT/32 and the constant $K_{21}$, using the previously determined $\boldsymbol{K}_{\mathrm{m}}$, was calculated. The constant $\boldsymbol{K}_{21}$ was determined at $1.585 \times 10^{11} \mathrm{M}^{-2}$.

DFT calculations: The Gaussian 09 software package ${ }^{[20]}$ was used in a two tier (ONIOM2) approach. ${ }^{[21]}$ The high layer was constituted of the simpler Zn(salphen) moiety and the bridging diamine whereas the remainder of the organic framework was modelled as the low layer (Figure S42). The high layer was described with the density functional approach namely the B3LYP gradient corrected hybrid three parameter functional ${ }^{[22,23]}$ built upon the Slater local exchange ${ }^{[24]}$ and the Vosko, Wilk and Nusair's local ${ }^{[25]}$ correlation (VWN formula 3) functionals. The basis set was of the Pople type contracted 6-31G(d,p) split valence basis set for all the elements. The low layer was described through the semi-empirical parametric model 6 (PM6) of Stewart ${ }^{[26]}$ employing valence only Slater type orbitals approximated by a primitive set of six gaussian functions (STO-6G) on all the atoms. The layer interface was composed of hydrogen link atoms. The total energy of the system can thus be computed $^{[21]}$ as: $E(O N I O M 2)=E_{\text {High layer }}$ (subsystem $)+$ $E_{\text {Low layer }}$ (Full system) - $E_{\text {Low layer }}$ (subsystem). The geometries were optimized without any constraints until the default convergence criteria were met. The electronic circular dichroism (ECD) rotatory strength values of the dinuclear complexes were computed with time dependent density functional theory $(T D D F T)^{[27,28]}$ as implemented in Gaussian 09 selecting thirty singlet to singlet transitions in an all electron single point calculation. The computed intensities were broadened by a Gaussian function to be comparable to the experimentally determined spectrum. For the tetra-nuclear complexes the calculation of their ECD spectra was exceedingly demanding to be performed in Gaussian 09 as it involves a very large number of excitations so it was opted to compute these ECD transitions with the $A D F^{[29]}$ program in which a single point calculation was performed on the previously optimized ONIOM geometry. A double zeta basis set was employed on all the light atoms while employing a triple zeta basis set on zinc. One advantage in favor of expediting this demanding calculation was the inclusion of a $[\mathrm{He}]$ and a $[\mathrm{Ne}]$ frozen cores on the light elements, and zinc respectively (apart from hydrogen). The basis sets were further augmented with one polarization $d$ function for $\mathrm{C}, \mathrm{N}$ and $\mathrm{O}$ and a $\mathrm{p}$ function for $\mathrm{Zn}$. A total of three hundred singlet to singlet excitations were 
calculated to reproduce the excitation spectra of the tetra-nuclear zinc complexes. The GGA class BLYP functional was employed rather than the aforementioned B3LYP used in Gaussian to eschew the computation of exact exchange integrals.

\section{Acknowledgements}

We thank ICIQ, ICREA and the Spanish Ministerio de Economía y Competitividad (MINECO) through projects CTQ-2011-27385, CTQ2011-29054-C02-02 and the Severo Ochoa Excellence Accreditation 20142018 (SEV-2013-0319). We also thank AGAUR for support through 2014-SGR-409. Dr. Noemí Cabello, Sofía Arnal and Vanessa Martínez are acknowledged for the mass analyses, and Dr. Gemma Aragay for help with the binding studies and data interpretation. NAGB gratefully acknowledges the CONFUND grant 291787-ICIQ-IPMP for financial support.

Keywords: calixarenes $\bullet$ chirality transfer $\bullet$ encapsulation $\bullet$ host-guest chemistry $\bullet$ salens

[1] a) G. A. Hembury, V. V. Borovkov, Y. Inoue, Chem. Rev. 2008, 108, 1-73; b) Supramolecular Chemistry, ed. J. W. Steed, J. L. Atwood, John Wiley \& Sons, Ltd., Chichester, New York 2000; c) Biochemistry, 2nd ed., eds. D. Voet, J. G. Voet, John Wiley \& Sons, Inc. New York 1995; d) M. V. EscárcegaBobadilla, A. W. Kleij, Chem. Sci. 2012, 3, 2421-2428; e) M. R. Ringenberg, T. R. Ward, Chem. Commun. 2011, 47, 8470-8476.

[2] For some examples: a) P. Dydio, C. Rubay, T. Gadzikwa, M. Lutz, J. N. H. Reek, J. Am. Chem. Soc. 2011, 133, 17176-17179; b) A. J. Boersma, J. E. Klijn, B. L. Feringa, G. Roelfes, J. Am. Chem. Soc. 2008, 130, 11783-11790; c) C. J. Brown, R. G. Bergman, K. N. Raymond, J. Am. Chem. Soc. 2009, 131, 17530-17531.

[3] a) H. Qiu, Y. Inoue, S. Che, Angew. Chem. Int. Ed. 2009, 48, 3069-3072; b) J. Wang, B. L. Feringa, Science 2011, 331, 1429-1432; c) N. Liu, G. R. Darling, R. Raval, Chem. Commun. 2011, 47, 11324-11326; d)
G. Haberhauer, Angew. Chem. Int. Ed. 2010, 49, 92869289; e) P. K. Hashim, N. Tamaoki, Angew. Chem. Int. Ed. 2011, 50, 11729-11730; f) K. Rijeesh, P. K. Hashim, S.-I. Noro, N. Tamaoki, Chem. Sci. 2015, DOI: 10.1039/C4SC01993H; g) H. Hayasaka, T. Miyashita, M. Nakayama, K. Kuwada, K. Akagi, J. Am. Chem. Soc. 2012, 134, 3758-3765.

[4] For a selection of recent examples: a) K. W. Bentley, Y. G. Nam, J. M. Murphy, C. Wolf, J. Am. Chem. Soc. 2013, 135, 18052-18055; b) L. A. Joyce, M. S. Maynor, J. M. Dragna, G. M. da Cruz, V. M. Lynch, J. W. Canary, E. V. Anslyn, J. Am. Chem. Soc. 2011, 133, 13746-13752; c) L. You, G. Pescitelli, E. V. Anslyn, L. Di Bari, J. Am. Chem. Soc. 2012, 134, 7117-7125; d) S. J. Wezenberg, G. Salassa, E. C. Escudero-Adán, J. BenetBuchholz, A. W. Kleij, Angew. Chem. Int. Ed. 2011, 50, 713-716; e) X. Li, M. Tanasova, C. Vasileiou, B. Borhan, J. Am. Chem. Soc. 2008, 130, 1885-1893; f) S. Nieto, V. M. Lynch, E. V. Anslyn, H. Kim, J. Chin, J. Am. Chem. Soc. 2008, 130, 9232-9233; g) M. Yamamura, T. Saito, T. Nabeshima, J. Am. Chem. Soc. 2014, 136, 1429914306; h) M. Anyika, H. Gholami, K. D. Ashtekar, R. Acho, B. Borhan, J. Am. Chem. Soc. 2014, 136, 550553; i) M. Balaz, A. E. Holmes, M. Benedetti, P. C. Rodriguez, N. Berova, K. Nakanishi, G. Proni, J. Am. Chem. Soc. 2005, 127, 4172-4173.

[5] a) V. V. Borovkov, G. A. Hembury, Y. Inoue, Acc. Chem. Res. 2004, 37, 449-459; b) J. Etxebarria, A. Vidal-Ferran, P. Ballester, Chem. Commun. 2008, 5939-5941; b) V. V. Borovkov, I. Fujii, A. Muranaka, G. A. Hembury, T. Tanaka, A. Ceulemans, N. Kobayashi, Y. Inoue, Angew. Chem. Int. Ed. 2004, 43, 5481-5485; c) V. V. Borovkov, G. A. Hembury, Y. Inoue, Angew. Chem. Int. Ed. 2003, 42, 5310-5314; d) M. Siczek, P. J. Chmielewski, Angew. Chem. Int. Ed. 2007, 46, 74327436; e) I. C. Pintre, S. Pierrefixe, A. Hamilton, V. Valderrey, C. Bo, P. Ballester, Inorg. Chem. 2012, 51, 4620-4635; f) X. Huang, N. Fujioka, G. Pescitelli, F. E. Koehn, R. T. Williamson, K. Nakanishi, N. Berova, J. Am. Chem. Soc. 2002, 124, 10320-10335. 
[6] M. V. Escárcega-Bobadilla, G. Salassa, M. Martínez Belmonte, E. C. Escudero-Adán, A. W. Kleij, Chem. Eur. J. 2012, 18, 6805-6810.

[7] See: a) C. J. Whiteoak, G. Salassa, A. W. Kleij, Chem. Soc. Rev. 2012, 41, 622-631; b) A. W. Kleij, Dalton. Trans. 2009, 4635-4639; c) S. J. Wezenberg, A. W. Kleij, Angew. Chem. Int. Ed. 2008, 47, 2354-2364.

[8] For literature dealing with $\mathrm{N}$-donors coordinating to aggregated $\mathrm{Zn}$ (salphen) type complexes and their UV-vis behavior: a) G. Salassa, M. J.J. Coenen , S. J. Wezenberg, B. L. M. Hendriksen, S. Speller, J. A. A. W. Elemans, A. W. Kleij, J. Am. Chem. Soc. 2012, 134, 7186-7192; b) M. Martínez Belmonte, S. J. Wezenberg, R. M. Haak, D. Anselmo, E. C. Escudero-Adán, J. Benet-Buchholz, A. W. Kleij, Dalton Trans. 2010, 39, 4541-4550; c) J. A. A. W. Elemans, S. J. Wezenberg, M. J. J. Coenen, E. C. Escudero-Adán, J. Benet-Buchholz, D. den Boer, S. Speller, A. W. Kleij, S. De Feyter, Chem. Commun. 2010, 46, 2548-2550.

[9] In order to assess the generality of this saturation effect, similar titrations were conducted with diamines $\mathbf{b}$ and $\mathbf{d}$ showing also saturation points in the $C D$ spectra at the addition of 0.5 equiv of the diamine guest.

[10] Zn(salphen) species show over time some decomposition in non-coordinating solvents in the absence of a stabilizing donor ligand; therefore the ${ }^{1} \mathrm{H}$ NMR studies were conducted in $\left[D_{6}\right]$ acetone despite the limited solubility of $\mathbf{1}$ in this solvent. See also: S. J. Wezenberg, E. C. Escudero-Adán, J. Benet-Buchholz, A. W. Kleij, Org. Lett. 2008, 10, 3311-3314.

[11] The $(M, M)$ and $(P, P)$ designations stand for the chiral conformations of both biphenyl units in $\mathbf{1}$ upon binding to chiral diamine a. Both $(M, P)$ and $(P, M)$ isomers of $\mathbf{1}$ are meso and should not give any signal in the $C D$ experiments.

[12] The fact that no observable Cotton effects were noted for neither of the substrates a-I in the presence of mono-nuclear complex 2 suggests that ditopic binding/coordination of the diamine substrate is requisite for efficient chirality transfer.

[13] a) A. W. Kleij, D. M. Tooke, M. Kuil, M. Lutz, A. L. Spek, J. N. H. Reek, Chem. Eur. J. 2005, 11, 47434750. b) S. J. Wezenberg, E. C. Escudero-Adán, J. Benet-Buchholz, A. W. Kleij, Inorg. Chem. 2008, 47, 2925-2927. c) E. Martin, M. Martínez Belmonte, E. C. Escudero-Adán, A. W. Kleij, Eur. J. Inorg. Chem. 2014, 4632-4641.

[14] S. J. Wezenberg, A. W. Kleij, Adv. Synth. Catal. 2010, 352, 85-91

[15] M. Cavazzini, A. Manfredi, F. Montanari, S. Quici, G. Pozzi, Eur. J. Org. Chem. 2001, 4639-4649.

[16] J. Y. Jang, D. G. Nocera, J. Am. Chem. Soc. 2007, 129, 8192-8198.

[17] The synthesis is based on the reduction of amineamide (S)-2-amino-2-phenylacetamine $\mathbf{k}$ using $\mathrm{LiAlH}_{4}$. See also: Y. Hsiao, L. S. Hegedus, J. Org. Chem. 1997, 62, 3586-3591.

[18] K. Lin, Z. Cai, W. Zhou, Zhongguo Yiyao Gongye Zazhi 2009, 40, 334-336. The synthesis of this amineamide is based on the preparation of Lphenylglycine methyl ester from the amino acid precursor followed by amidation in ammonia, with an overall yield of about $65 \%$.

[19] SPECFIT32: Specfit/32, version 3.0; Spectra Software Associates: Bradford-on-Avon, U.K., 2005. Specfit/32 is a multivariate data analysis program for modeling and fitting multi-wavelength titration data sets giving more reliable parameters than singlewavelength fits. For software details and the related nonlinear algorithms see: H. Gampp, M. Maeder, C. J. Meyer, D. A. Zuberbühler, Talanta 1985, 32, 95-101; H. Gampp, M. Maeder, C. J. Meyer, D. A. Zuberbühler, Talanta 1986, 33, 943-951. 
[20] M. J. Frisch, G. W. Trucks, H. B. Schlegel, G. E. Scuseria, M. A. Robb, J. R. Cheeseman, G. Scalmani, V. Barone, B. Mennucci, G. A. Petersson, H. Nakatsuji, M. Caricato, X. Li, H. P. Hratchian, A. F. Izmaylov, J. Bloino, G. Zheng, J. L. Sonnenberg, M. Hada, M. Ehara, K. Toyota, R. Fukuda, J. Hasegawa, M. Ishida, T. Nakajima, Y. Honda, O. Kitao, H. Nakai, T. Vreven, J., J. A. Montgomery, J. E. Peralta, F. Ogliaro, M. Bearpark, J. J. Heyd, E. Brothers, K. N. Kudin, V. N. Staroverov, R. Kobayashi, J. Normand, K. Raghavachari, A. Rendell, J. C. Burant, S. S. Iyengar, J. Tomasi, M. Cossi, N. Rega, N. J. Millam, M. Klene, J. E. Knox, J. B. Cross, V. Bakken, C. Adamo, J. Jaramillo, R. Gomperts, R. E. Stratmann, O. Yazyev, A. J. Austin, R. Cammi, C. Pomelli, J. W. Ochterski, R. L. Martin, K. Morokuma, V. Zakrzewski, G. A. Voth, P. Salvador, J. J. Dannenberg, S. Dapprich, A. D. Daniels, Ö. Farkas, J. B. Foresman, J. V. Ortiz, J. Cioslowski, D. J. Fox, Gaussian'09 rev. D.01.

[21] M. Svensson, S. Humbel, R. D. J. Froese, T. Matsubara, S. Sieber, K. Morokuma, J. Phys. Chem. 1996, 100, 19357-19363.

[22] A. D. Becke, J. Chem. Phys. 1993, 98, 56485652.

[23] C. Lee, W. Yang, R. G. Parr, Phys. Rev. B 1988, 37, 785-789.

[24] J. C. Slater, Phys. Rev. 1951, 81, 385-390.
[25] S. H. Vosko, L. Wilk, M. Nusair, Can. J. Phys. 1980, 58, 1200-1211.

[26] J. Stewart, J. Mol. Model. 2007, 13, 11731213.

[27] C. Adamo, D. Jacquemin, Chem. Soc. Rev. 2013, 42, 845-856.

[28] A. Rosa, G. Ricciardi, O. V. Gritsenko, E. J. Baerends, Struct. Bond. 2004, 112, 49-116.

[29] E. J. Baerends, J. Autschbach, A. Bérces, C. Bo, P. M. Boerrigter, L. Cavallo, D. P. Chong, L. Deng, R. M. Dickson, D. E. Ellis, M. van Faassen, L. Fan, T. H. Fischer, C. F. Guerra, S. J. A. van Gisbergen, J. A. Groeneveld, O. V. Gritsenko, M. Grüning, F. E. Harris, P. v. d. Hoek, H. Jacobsen, L. Jensen, G. van Kessel, F. Kootstra, E. van Lenthe, D. A. McCormack, A. Michalak, V. P. Osinga, S. Patchkovskii, P. H. T. Philipsen, D. Post, C. C. Pye, W. Ravenek, P. Ros, P. R. T. Schipper, G. Schreckenbach, J. G. Snijders, M. Sola, M. Swart, D. Swerhone, G. te Velde, P. Vernooijs, L. Versluis, O. Visser, F. Wang, E. van Wezenbeek, G. Wiesenekker, S. K. Wolff, T. K. Woo, A. L. Yakovlev, T. Ziegler, ADF, http://www.scm.com, Scientific Computing and Modelling ADF-2013.01. 


\section{Entry for the Table of Contents}

\section{FULL PAPER}

A calix[4]arene functionalized with two $\mathrm{Zn}$ (salphen) complexes shows highly effective chirality transfer effects in the presence of chiral diamines. The operating modus of the system involves a unique encapsulation of the diamine guest.

Experimental and computational studies support the highlv cooperative nature of

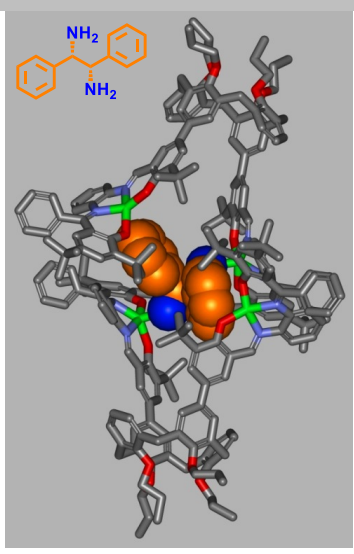

Luis Martínez-Rodríguez, Nuno A.

G. Bandeira, Carles Bo and Arjan

W. Kleij*

Page No. - Page No. 